\title{
3. Non-Pristine Forests: A Long-Term History of Land Transformation in the Western Solomons'
}

\section{Forests of New Georgia: Understanding the Long Run}

The rainforests of the large mountainous islands of Melanesia are routinely assumed by outside observers to be an example of last remaining wilderness, high in biodiversity, valuable to humankind in general, and somehow largely undisturbed by humans until logging operations escalated in recent decades. But the fact that most Melanesian islands have substantial numbers of people living inland, or at least had inland populations until quite recently, would undermine such assumptions. As Bennett (2000: 18-26) expresses in her

\footnotetext{
1 This chapter builds on a larger multidisciplinary study of the long-term dynamics of human interactions with the rainforest in the Marovo Lagoon area of the Western Solomons, carried out with Tim Bayliss-Smith and the late T.C. Whitmore from 1996 onwards (Hviding and Bayliss-Smith 2000; Bayliss-Smith et al. 2003; Bayliss-Smith and Hviding 2012, 2014a, 2014b). Details of this study will be given below. As anthropologist, geographer and forest botanist, the three of us were able to share our field observations and insights from the Solomon Islands 'logging boom' of the 1990s, as well as to relate our longer-term experiences from the scenes of forestry and land use in Solomon Islands, in Whitmore's case reaching as far back as to his work as a government forest botanist in the British Solomon Islands Protectorate in the 1960s (Whitmore 1969). I am grateful to Tim and Tim for all those inspiring discussions in Cambridge and elsewhere. In this context I also would like to express my deep respect for the late T.C. Whitmore's continuous insistence as a botanist on the human factor in rainforest dynamics.
} 
history of human interactions with forests in Solomon Islands, the rainforests encountered by the first settlers of the archipelago were 'opened up' by them tens of thousands of years ago: 'To the ancestral Melanesians and their more recent counterparts, the forests were a huge garden, with some part, for a time, being more intensively used than others' (ibid.: 19). From the 'arboriculture' and modest modifications by early human settlers, through the development of shifting agriculture based on burned clearings to present-day large-scale land transformations, the forests of the Solomons (and elsewhere in Melanesia and Oceania more widely) have histories that are closely interconnected with human habitation and activity in those forests (e.g., Bayliss-Smith et al. 2003). The continuous human agency in the long run of forest history has interacted ecologically with the fluidity and dynamic characteristic of the tropical forest itself, including its ability to regenerate after significant disturbance (cf. Whitmore 1990).

The forests of the New Georgia group of the Western Solomons, which are the focus of this chapter (Figure 3.1), have remained of particular interest both to logging operators and conservationist organisations, while consistently providing the majority of timber exports from the country since the 1980s. In New Georgia, the Asian (and increasingly Melanesian) protagonists of the Solomon Islands 'logging boom' that accelerated in the 1990s (Bennett 2000; Hviding and Bayliss-Smith 2000), as well as their colonial British precursors, saw islands with scattered seashore habitation, modest areas of forest clearance for shifting cultivation on the coastal slopes, and no inland villages. Dense rainforest still extended from coast to coast across steep ridges, extinct volcano craters, limestone pinnacles and mountain peaks, some reaching 800-1,000 metres above sea level. This, obviously, was also the deceptive scenery encountered by the conservationist adversaries of the loggers. 


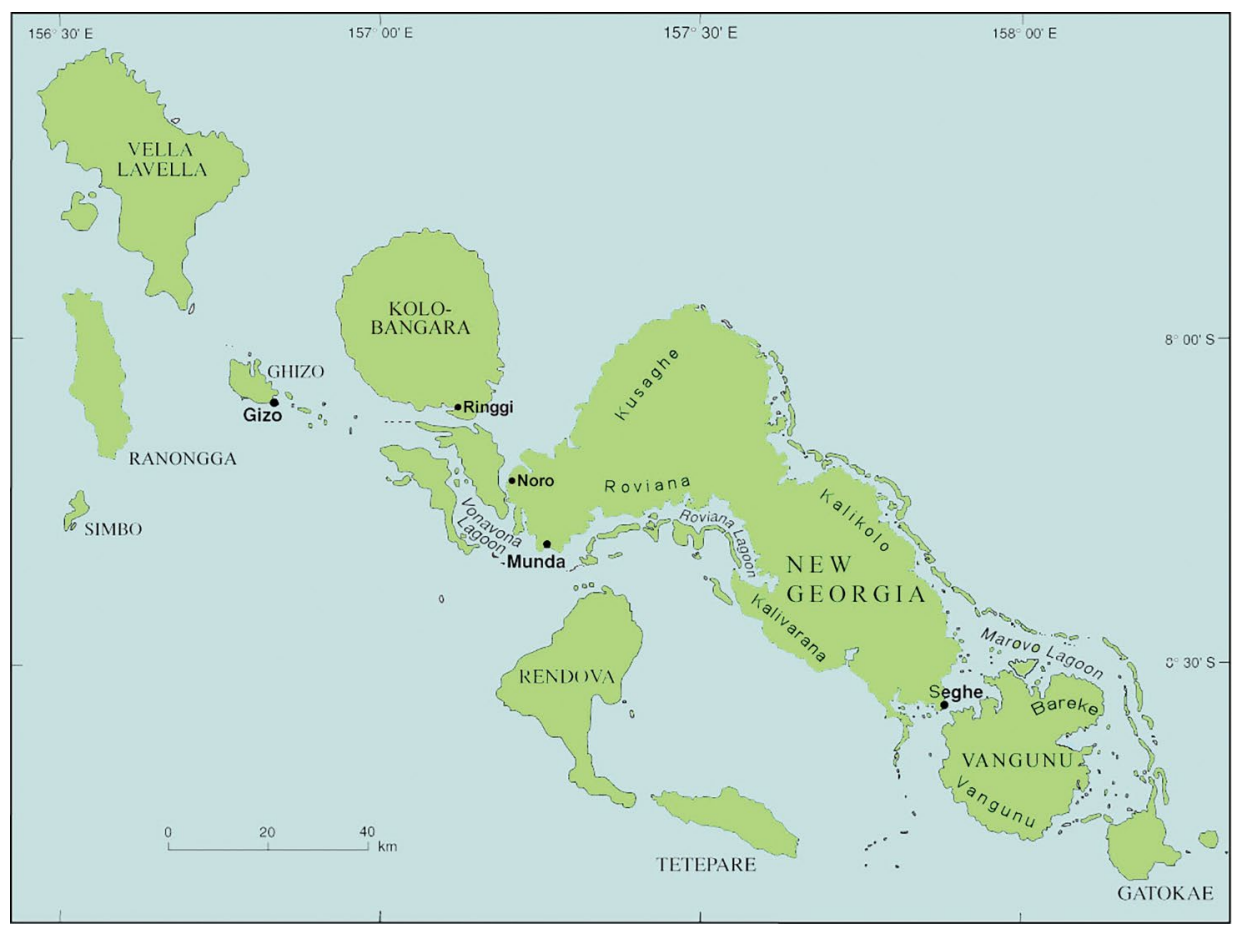

Figure 3.1 The New Georgia Islands, Solomon Islands.

Source: K.H. Sjøstrøm, University of Bergen.

What was not evident to outside observers was that the forests of New Georgia were in no pristine natural state when large-scale logging commenced. Despite the apparent intact quality in the 1980s of the New Georgian rainforest canopy, the forests were ecosystems in which the interaction with, and transformational influence of, human populations had played a major role through thousands of years. In fact, until the end of the nineteenth century the vast inland tracts of rainforest that were to become the subject of so much contestation were lands under extensive shifting cultivation and intensive river-fed irrigation, supporting large populations of inland dwellers. The assumedly undisturbed natural forests of late twentieth-century New Georgia had therefore regenerated from widespread, continuous human disturbance that only abated in the late nineteenth century (Bayliss-Smith et al. 2003). In this observation from the Western Solomons lies a challenging but potentially fruitful analytical interaction in the study of long-term land use, between separate paradigms of political ecology and historical ecology (see Blaikie and Brookfield 1987; Balée 1998; Robbins 2004). In the case of the New Georgia Islands, with obvious bearings for much of the Melanesian region, the understanding of the complex presentera politics of resource use and related conflict through 'political ecology' needs 
to rely more strongly on the truly long-term perspectives of 'historical ecology' concerning human-environmental interactions. Insights from botany are also a required element in the deepened understanding of rainforests as non-pristine.

Let me shift to recent political issues for the Western Solomons, New Georgia and the Marovo Lagoon. These are well-known fields of contestation that represent a common pattern in contemporary Melanesia. It is in fact not only the logging companies that have hit the forests of the Western Solomons in recent decades. While in the 1990s, Asian companies made rapid inroads into forests that seemed untouched except for tracts of land that had already been logged over to some degree by a colonial company called Levers Pacific Timbers, a plethora of international conservation organisations also descended on the islands and their forests: particular attention was given to the famous Marovo Lagoon in south-east New Georgia, a lagoon that covers about 700 square kilometres and is fringed by a unique double chain of raised barrier reefs and by the high volcanic islands of the eastern half of the New Georgia group (Hviding 1996a). The collective agenda of these organisations, which among them had the major international players WWF (World Wide Fund for Nature) and Greenpeace as well as smaller non-governmental organisations that were in fact more or less extended arms of Australian and New Zealand government interests, was to present to the world the idea that Solomon Islands in general, and the lands surrounding the Marovo Lagoon in particular, were places of pristine, some would say virgin, rainforest that had never been significantly disturbed by human activity (Hviding 2003a). But were those forests pristine? Or, as asked in general terms by a team of tropical forest ecologists: how 'virgin' is virgin rainforest? (Willis et al. 2004).

My own continuing work since 1986 in the Marovo Lagoon and surrounding islands has been inextricably tied to the increasingly complicated contestations surrounding the forests of the area. When I first arrived there, I was thrown straight into the aftermath of the conflict that resulted in the final departure from the Solomons of colonial survivor Levers Pacific Timbers. That company had been operating 'scientific forestry' (which frequently seemed to be a poor disguise for agendas of clear-felling) for several decades in the Western Solomons, mainly on land obtained by the colonial administration as 'forest estate' through purchase from customary, kin-based landholding groups referred to throughout New Georgia as butubutu (see Hviding 2003b). But in the 1980s, only a few years after Solomon Islands gained independence in 1978, Levers Pacific Timbers operations ground to a halt after the company shifted its operations to customary land, having exhausted the tracts of 'forest estate'. Forceful local opposition was met with in northern New Georgia. As I got to know the notoriously stubborn and independently minded people of a prophet-led rural movement called the Christian Fellowship Church (CFC) who had the distinction of having made 
life for Levers Pacific Timbers unbearable, I quickly learned that they had not burned bulldozers, menaced company labourers (non-violently), taken a hand in provincial politics and ultimately caused the fall of this transnational giant's operations in New Georgia out of conservationist sentiments. Instead, they had done so in defence of their own autonomy as rural landholding groups, and in defiance of a colonial regime and a young national government that were seen to be conspiring with Levers to gain access to timber on customary lands in clever legalist ways aimed at bypassing the legal privilege of customary landowners (Hviding 1996a: 316-20).

Surely, if the eyes of the powerful international lobby of rainforest conservation and indigenous rights activism had been focused on the Solomons in the mid1980s, the people of northern New Georgia, and especially the colourful and exotic CFC movement - with its powerful prophet the Holy Mama, who so well mixed traditionalism, modernist development aspirations, United States Army inspirations from World War II and singular worship practices - might have entered centre stage on the global scene as prominent tribal conservationists, perhaps alongside Amazon Indians. But the major international organisations had not then arrived in the Solomons. And the fact that New Georgians never really saw themselves as occupants of the tribal conservationist slot was amply demonstrated when in 1989 the leaders of the CFC, in their capacity as managers of vast forests, invited an Indonesian company to enter their lands and log that which Levers had left.

Since then, the northern and western parts of the island of New Georgia have seen massive land transformation through selective logging and, in designated areas subject to clear-felling, the development of large, locally owned tree plantations where Eucalyptus, Gmelina, teak and mahogany are grown in conjunction with garden crops. The development of teak plantations has been particularly extensive. But at the opposite end of the Marovo Lagoon, the large island of Vangunu has experienced a chaotic multitude of logging by many operators, and a large tract of government land on the island's south-eastern side, alienated in colonial times, has been clear-felled for the ostensible purpose of establishing a Malaysian-owned oil palm plantation which never became operative. The forests of New Georgia that in the 1980s and early 1990s appeared to outside observers as pristine, with dense canopies covering the land from coast to coast across mountain ridges, have been forever changed (Hviding 1996a; Hviding and Bayliss-Smith 2000). This process is, however, not difficult to grasp through the eyes of the Marovo people, in whose history there is a long and continuous record of transforming that which is 'wild' (piru) and outside the human domain into the condition of 'domesticated' (manavasa). Neither of these two states are regarded in Marovo as definite - thus 'wild' forest is not a timeless wilderness, but usually forest that has reverted from being 'domesticated' (Hviding 1996b). 
At the edge of the 'domesticated', Marovo people have always seen new 'wild' spaces to be drawn into the former sphere by human activity. The scale of such transformation has escalated in recent and present times, though. But, as will be shown below, larger-scale permanent land transformation has increasingly become part of the local land use repertoires in the twenty-first century, as the people of Marovo Lagoon and wider New Georgia have devised new approaches to managing lands whose forest has been radically changed through logging. In the present, external and indigenous agendas for land transformation have merged, but this has taken place against a background of quite extraordinary forest modification in the past.

\section{Forests and People in Old New Georgia: Cultural History and the Evidence of Botany}

Over the past 30 to 40 years a new paradigm for rainforest ecology has been developed, in which forest disturbance is given a central role in the maintenance of botanical diversity. Gaps that are created in the forest canopy are seen as generating a range of different microhabitats, while forest tree species can be classified along a continuum from light-demanding to shade-tolerant, according to how much sun they require for regeneration. Two broad classes of tree are significant in this 'gap-phase' paradigm: pioneer species and climax species. Pioneer species germinate and establish growth only in full light in a gap after its creation, and their seedlings are not found growing below a full and undisturbed canopy (Whitmore 1984, 1990, 1998). In this view, rainforests reach their highest levels of species richness when they are in an intermediate stage of recovery from disturbance, or when disturbance is at an intermediate intensity or frequency. In these intermediate states the forest will contain the fullest repertoire ranging from pioneer species to climax species, and its biodiversity is at a maximum (Connell 1978).

How can the gap-phase paradigm be made relevant for interpreting the dynamics of forests so easily construed as 'natural' or 'virgin' in the snapshot insights of outsiders? The Marovo area lends itself well to such discussion owing to inherent contradictions. Until the early twentieth century the Marovo Lagoon, like its political counterpart and oftentimes enemy Roviana Lagoon further west, was the scene of large-scale maritime exchange and predatory warfare, as well as the hub of a regional economy based on the large-scale irrigation of Colocasia taro (talo) in pondfields (ruta) constructed in the forest (Bayliss-Smith 
and Hviding 2012, 2014a). ${ }^{2}$ The contradictions in question are grounded in both the pre-colonial and the post-colonial. On one hand, the Marovo area has a complex history of centuries of agricultural intensification, inter-island contacts and sociopolitical transformations, yet on the other, the lagoon's catchments and its forested islands have in recent decades figured in international media as a prominent example of pristine tropical wilderness. It is well known that Marovo has on several occasions been proposed for permanent conservation, even as a possible UNESCO World Heritage site (Hviding 2003a).

The distinguished rainforest botanist T.C. Whitmore, who not only developed the gap-phase paradigm but also was the undisputed authority on the vegetation of the Solomon Islands, noted that the islands' forests below 300 metres are in many ways similar to forests throughout South-East Asia and New Guinea. However, Solomon Islands forests are lower in height, have fewer emergent trees but more epiphytes and climbers, and are impoverished in species diversity. In the forests of the Western Solomons specifically, the canopy, which is 30-45 metres tall but lower on steep slopes and at higher altitudes, is locally broken by gaps filled with climbers and thickets of smaller trees. The key to understanding some important long-term processes in these forests is a 30-50 metre tall tree called Campnosperma brevipetiolata. From his extensive surveys in the 1960s of forests in the British Solomon Islands Protectorate, Whitmore noted that, especially in the New Georgia Islands and on Santa Isabel, large areas of lowland forest were almost totally dominant at canopy level by this tree. Since Campnosperma is a light-demanding species that requires gaps in order to grow, any forest dominated by it must be the site of considerable canopy disturbance. At the time, Whitmore attributed this rather strange vegetation pattern to significant human disturbance in the areas concerned up to the end of the twentieth century, noting for vast tracts of southern Isabel where 45 per cent of large trees were Campnosperma that 'this particular area may well date from the abandonment of cultivations following the decimation of the local people by raiding parties from New Georgia across the Sound, which is known to have occurred within living memory late last century' (Whitmore 1969: 265). Later, his influential voice in the botanical understanding of Solomon Islands forests changed into proposing a relationship between recurrent tropical cyclones and a predominance of Campnosperma at canopy level.

2 In this paper vernacular terms are given in the Marovo language, which is a secondary doctrinal language of the CFC and of the United Church, and a primary one for the SDA Church. The latter is the numerically dominant denomination in the Marovo Lagoon. Marovo is also the field language I use. The coexistence in New Georgia of the two closely related languages Marovo and Roviana thus is strongly connected to mission history as well as to geographical distinctness, but on an everyday basis most adults in New Georgia, wherever they live and whatever church they belong to, are able to speak both languages. 
This is where my own work on the political ecology of forests in the Marovo Lagoon intersected with Whitmore's observations, mediated through a mutual friend and colleague, geographer Tim Bayliss-Smith. Conversations in Cambridge led to collaborative work of longer scope. In 2000, Bayliss-Smith and I published the book Islands of Rainforest, where we took up Whitmore's old argument that Campnosperma-dominant lowland forest indicated past human disturbance. We used this insight to interpret exquisitely detailed foresttype maps produced in late colonial times, and we concluded that a canopy dominance of Campnosperma characterised areas that were known from oral history and from personal observations to be sites of substantial past settlement and extensive irrigated taro cultivation. Thus there seemed to be no doubt that this type of species-poor forest, so characteristic of much of New Georgia, was a messenger of widespread forest transformation up to the late pre-colonial and early colonial years. From about the end of the nineteenth century, as the systems of exchange and tribute that governed relationships between the coastal and inland dwellers of New Georgia collapsed with the end of inter-island warfare and head-hunting and with the arrival of British naval power, Christian missions and other sweeping changes, inland settlements and their associated irrigated taro pondfield systems (ruta) were gradually abandoned. By the late 1930s few ruta were left in operation anywhere in New Georgia. ${ }^{3}$ When the coastal villagers of Marovo retreated into the bush in 1942 in fear of the oncoming war machines of Japan and the United States, pondfields were already so overgrown as to discourage any attempt at returning to growing wetland taro, and wild yams instead became the staple diet. With the abandonment of pondfields the heavily modified forests with broken canopies regenerated, but into a particular Campnosperma-dominated ecological configuration.

Bayliss-Smith, Whitmore and I soon embarked on a collaborative study for which we combined a range of botanical, ecological, archaeological, demographic and anthropological materials to conclude once and for all that the lowland forests of New Georgia as they appeared just before logging accelerated in the late twentieth century were not in any way 'virgin'. Instead, they were a lowdiversity form of secondary growth, rich in large timber species, produced by continuous human intervention over many generations up to the late nineteenth century, or in some forests even more recently. This analysis allowed us to use the finely detailed colonial forestry maps to estimate the extent of land under dryland and irrigated cultivation around $1870-80$, as well as to propose a number of demographic scenarios for the undoubtedly substantial inland populations

3 Wetland taro cultivation in small pondfields along tributaries of major rivers has continued on a very small scale, but as an unbroken practice, in a few locations in northern New Georgia inhabited by traditionalist people of the CFC. They are also believed to carefully preserve small intact stocks of talo ruta or 'pondfield taro' growing in water even where there are no pondfields. Here and there along riverbanks in these parts of New Georgia, this form of wetland taro can also be found in feral condition. 
of bygone days. The population estimates made for the main area of Marovo Lagoon in the period $1870-80$ gave ranges from about 12,000 to about 22,000 people, compared to the 1986 population of less than 7,000, which has increased to a 2010 population of about 15,000 (Bayliss-Smith et al. 2003: 348-51; see also Hviding and Bayliss-Smith 2000: 138-40).

\section{Tales of the Past, Misconceptions of the Present}

That the empty inner lands of the New Georgia Islands were well settled in the past is not contested. Most customary landholding groups (butubutu) today maintain repertoires of stories about inland settlements, ancestral shrines, ceremonial grounds and old groves of Canarium nut trees, framed in a genealogical perspective. Indeed, such stories are becoming all the more significant in the present-day context of inter- and intra-group disputes over customary rights to land - there is a direct correlation between recognised entitlements to customary land and the current flow of timber royalties from logging companies. In that sense, then, tales of the past inland settlement of one's landholding butubutu may feed straight into the realm of bank accounts for royalties and into conspicuous consumption.

Not many generations span the time from when the inland forest became disused except for occasional forays for feral pigs; most of the interior of the New Georgia Islands was not entirely abandoned until the early twentieth century. From his work in the Marovo Lagoon as a surveyor for the Royal Navy in the 1890s, Lieutenant H.B.T. Somerville reported on a cautious expedition in 1893 that ventured quite far inland and uphill on the northern part of Vangunu Island. Most surprising to the Royal Navy representative was the inland population his party encountered:

This small expedition into the bush ... points out that (1) Most of the people of this district live away from the sea coast. (2) That, however, they are probably in the habit of visiting the coast for trade etc. (Somerville 1893: 5)

In a somewhat later, more lurid missionary's tale, an account is given of how three young boys of a group of 'saltwater people', recently converted to the Seventhday Adventist (SDA) faith (but later to become leading missionaries in their own right and tell their boyhood tale to the writer in question), experienced the inner lands of south New Georgia during a forced bushwalk in 1915 back from the mission station at Viru Harbour:

Trekking through the dense jungle, the three youths crossed parts of New Georgia, carefully bypassing strange villages, devil-dancing grounds, and piles of sacred spirit stones in the forest groves. They were out of their territory and among 
enemies. They had no desire to provoke the wrath of the people or their spiritgods. Happily they found the coast and from a friendly old woman borrowed a canoe and paddled across the lagoon to their own shores. (Were 1970: 26)

As boys of a coastal group with little experience of life in the interior, they are likely to have been acutely aware of the strange world they encountered. The continuing existence of a number of interior settlements in Marovo and in northern New Georgia as late as 1910-15 is in line with the conventions of oral history in the area, as well as with some eyewitness accounts by missionaries and travellers.

But in most of New Georgia the interior had been depopulated by the turn of the century. As the inner lands were abandoned by all those people indicated by our population estimates - numbers that may have been decimated because of epidemic diseases known to have had locally devastating consequences from around 1870 - old settlements and finely engineered pondfield systems for taro were left to the encroaching forest. Concurrently a new form of land transformation took place from the early years of the twentieth century in areas closer to the lagoon coast. This was the very first intervention of the global political economy into the forests of the Western Solomons, and it preceded the logging boom of the 1990s by almost 100 years (Hviding and Bayliss-Smith 2000: 150-9). The rapid build-up of a coconut economy throughout New Georgia caused large areas of shoreline forest, sago palm stands and mangrove vegetation to be cleared and replaced by coconut groves. The hillsides closest to the growing coastal villages were now placed under intensive shifting cultivation of food crops, and the only interior forest features still receiving attention from a people now fully coastal were old groves of Canarium nuts, still tended through the regular removal of undergrowth and invading climbers. The massive tracts of remaining inland forest were simply left to regenerate, with the inevitable dominance of Campnosperma brevipetiolata in many of those areas that had been most heavily modified by centuries of pondfield construction and maintenance. This, then, was the forest scene encountered by loggers and conservationists alike in the late twentieth century - a robust-looking forest with a dense canopy and an abundance of tall trees festooned with climbers and orchids, seen by the former as timber-rich and by the latter as pristine/primary/virgin. Gregarious creepers, climbers and herbaceous forest floor shrubs hid most signs of past human habitation from those not in the know, but for locals who did know, the history of human habitation and forest modification were there to see.

Quite a different, and markedly less dynamic, interpretation has been presented by agents of forest conservation, who have seemed to be reluctant to consider anthropogenic disturbance as a ubiquitous feature of the forests in places like 
Solomon Islands. For example, as the logging boom was gaining momentum, a New Zealand conservation organisation presented its case to the Australian government, the principal aid donor to Solomon Islands, as follows:

The proposed protected area [i.e., the forests of Marovo Lagoon] has been little disturbed: hurricanes are infrequent and of low intensity, and human impact has been limited to gardened land and some timber removal on Vangunu and Nggatokae. The result is a region of extensive primary forest cover, including undisturbed forest community transitions from the sea to mountain tops. (Lees et al. 1991: 95)

Let this quote stand as representative for an environmentalist view not informed by either cultural history or by rainforest ecology. A contrasting view of those same forests not as 'undisturbed' at any time would focus instead on their ecological resilience under successive stages of transformation, not only after centuries of regular disturbance for settlement and agriculture, but even, and notably so, in the face of modern logging operations. Observations by Tim Whitmore in the mid-1990s in fact indicated successful regeneration of logged forests, even in northern New Georgia where clear-felling by Levers Pacific Timber had resulted in a long delay of regeneration as degraded areas were invaded by creepers such as Merremia. Fourteen years after this most severe disturbance, Campnosperma and Pometia trees had pushed their way through the carpet of creepers to reach a height of 13 metres (Whitmore 1995). Whitmore argued that a succession back to mixed forest seemed to be assured given no additional human disturbance. It is a fact that, unlike Levers, few of the Asian companies operating in New Georgia since the 1990s have had agendas of clear-felling. Instead they have preferred to work over often volatile logging concessions on customary land in a quick and often confused manner, crisscrossing the land with dirt roads and skid tracks and ripping out as many valuable trees as possible before any trouble with landowners arises. Ironically, this rough and rapid approach leaves far more vegetation standing than the scientifically informed clear-felling carried out by Levers. Total forest loss through the planting of oil palms in logged areas remains a sinister possibility, though, and was indeed envisaged for the notorious tract of government land on Vangunu clear-felled in the 1990s by Silvania Products of Malaysia, although it never happened. More diverse post-logging trajectories have been evolving in local hands. 


\section{Transforming the Forest: Logging, 'New Life' and Multiple Trajectories}

As the twentieth century drew to a close, new scenarios were to be developed in the historical and political ecology of New Georgia's forests. While logging by a bewildering range of companies in central Marovo proceeded in a chaotic fashion, creating scars in both landscape and social life, the northern areas under control by the CFC, once the bane of Levers Pacific Timbers, followed a different course. From 1989 until today, logging in the area has with few exceptions been carried out by only one company - Golden Springs International of Indonesia (where it operates as Sumber Mas, of which 'Golden Springs' is a translation). Golden Springs operations have been managed in close consultation with the leaders of the CFC, whose organisation functions as a corporate tool for combining the control over several dozen tracts of customary land throughout northern and western New Georgia held by the constituent kin groups of the movement. The encompassment of church leadership, since the days of the Holy Mama, of land rights vested with a large number of individual butubutu throughout New Georgia, constitutes the movement's main corporate power base (Hviding 2011: 9-10). Although exact details of the agreements between company and church are elusive given the secretive nature of the CFC, it is a well-known fact that its royalty rates are far higher than for any other logging operation in the Western Solomons, and probably the highest anywhere in Solomon Islands. It is my impression that the willingness of Golden Springs International to provide substantially higher royalty rates over several decades is directly tied to the benefits the company receives from its extraordinarily long-term presence in the land.

Leaders and adherents of the $\mathrm{CFC}$, as well as informed non-CFC observers, make no bones about the considerable wealth accumulated by this movement over the years. Indeed, wealth accumulation is an integrated aspect of a doctrinally central concept of 'New Life' to be attained for followers. The financial system of the CFC manages flows of logging-generated revenue from the periphery of customary landowners (on whose land logging operations take place) to the centre of church leadership. This accumulation is a centralised one that keeps timber royalties virtually outside the village economy and instead supplies villages with services such as schools, health facilities and transport. This can be seen as a new twist on old Oceanic patterns of chiefly redistribution, and was a strategy not least significant at the dawn of the twenty-first century when the already meagre government services to rural areas were disrupted during the so-called 'Tension' - a condition of limited civil war (mainly on the island of Guadalcanal) leading to a collapse of both government and national economy (Moore 2004; Allen 2013). More specifically, the CFC consolidates fragmented 
kin-based authority over land by collectively organising customary landowning groups in large-scale ways that lack parallels elsewhere in the Solomons. A range of self-initiated economic development projects are operated by the various arms of the CFC organisation, through an approach that avoids collaboration with non-governmental organisations and refuses most outside aid, instead relying on its own funding in the form of accumulated logging royalties.

With its somewhat peculiar forms of worship, and its insistence that its leader is the earthly manifestation of the Holy Spirit, the CFC has, since it was established through a breakaway from the Methodist Mission in the 1950s, been regarded with distrust by many Solomon Islanders. Thus knowledge of its singularly successful way of adapting to the logging boom remained limited. The public image of the CFC in Solomon Islands was improved and national-level knowledge of the movement expanded with the unexpected media coverage given in 2005 of two high-level visits to the CFC headquarters at Duvaha in North New Georgia, first by the prime minister, then by the governor-general. Further national media attention was given later that year with the bestowment of a knighthood by Queen Elizabeth II upon the CFC's spiritual leader, the Reverend Ikan Rove, who visited London for the occasion. Known to CFC adherents as the Spiritual Authority, Reverend Rove is the son of the Holy Mama, who founded the movement and brought it into a recognised state as an independent, indigenous church by 1960. Since succeeding his father, Reverend Rove has seen it as his foremost mission to promote economic development for his people, moving them into a new era he has designated the 'time of development' (kolokolo divelopmen). In line with this, the large-scale development by the CFC since 2000 of huge tree plantations on customary land logged and clear-felled by the Golden Springs company, particularly the communal planting of what must be hundreds of thousands of teak trees, has caught attention in the national search for post-conflict options for rural development, although being seen as somewhat of an enigma by foreign proponents of 'community development projects' (e.g., Makim 2002; see also Hviding 2011).

In the Western Solomons, environmental histories of forests are, as will be clear by now, closely connected to the different paths followed by the three church denominations of these islands: the CFC, the United Church (formerly the Methodist Mission), and the SDA Church. ${ }^{4}$ When the Asian logging boom hit Solomon Islands in the early 1990s, the CFC was ready to take the fullest advantage of its already existing corporate system of amalgamated customary

4 See Hviding (1996a: 118-24) for mission history and more recent developments in Marovo Lagoon and McDougall (2008) for more general comparison of the potential roles of different denominations for generating rural development in the Western Solomons. Hviding (2011) gives a comprehensive analysis of the history of the CFC and the movement's most recent accomplishments. The account that follows is based on seven separate field visits throughout New Georgia between 2003 and 2012. 
land under centralised authority. As logging accelerated, many SDA groups of central Marovo and northern New Georgia found themselves at an advantage as major landowners through their long-term history as 'bush people' whose previous generations had lived and worked in the interior. In contrast, the original strongholds of the SDA faith in the Solomons remained largely landless, determined by their history as sea- and reef-holding coastal or 'saltwater' groups of central Marovo Lagoon, easily contacted by the pioneer SDA missionaries. As logging gained momentum, the inequalities among New Georgia's SDAs in terms of landholdings, coupled with the bilaterality of kinship throughout Marovo and Roviana, generated massive land disputes that were further deepened by the fact that 'saltwater' people with limited primary rights to land remained the most influential in church matters. Nevertheless, a great number of logging operations commenced on SDA land, but with the majority of landholding butubutu having no resident chief (since most younger chiefs had become urban elite), a lack of planning has resulted in a chaotic picture where almost every SDA butubutu with significant landholdings has engaged its 'own' logging company. This chaos is inscribed on the SDA lands of central Marovo - known as the Bareke hills of northern Vangunu - where a dense and confused pattern of logging roads and shipment ponds mar the hills and coastlines. In 2007 I observed approximately one log shipment pond for every 4 kilometres of coastline in central Marovo, whereas in the CFC areas of northern Marovo the log shipment ponds were up to 20 kilometres apart and the logging road network was much more orderly.

A similar contrasting picture characterised the financial side of logging. I have already described the CFC system of keeping timber royalties out of the village economy, centralising and accumulating the funds, and carrying out regular redistribution to church members in the form of subsidies of school fees, tax obligations and rural infrastructure. Among the SDAs, timber royalty rates have generally been lower than those of the CFC, owing to the poor bargaining situation of fragmented butubutu and weak internal leadership. Still, a large number of logging operations on SDA land have generated substantial income, much of which has been disputed through court cases. Whatever the outcome of these cases, the final recipients of royalties among the SDA groups have spent most of the money on consumption goods, short-lived investments such as outboard motors, and a profusion of not always durable houses of permanent materials. Apart from a number of very impressive church buildings now standing more or less finished in villages of central Marovo (reflecting an emphasis among Adventists and Methodists on large churches as rural status symbols), few enduring results are to be seen today from 10-15 years of huge windfall profits from logging. The lands are devastated by the unplanned use of logging machinery, and subsistence gardening suffers. Typically, the SDAs (who for sectarian reasons have always refused to have government-operated schools) 
still have to pay substantial annual school fees for their children at primary and secondary schools, and the quickly evaporated royalties have not assisted families in this arduous task.

While the Methodist (or United Church) villages of Marovo and of New Georgia more widely all have government schools and so are not burdened with school fees at the level of the SDAs, they have otherwise lost out on most scenes of contemporary political economy in the Western Solomons, dependent as these scenes are on the attainment and management of windfall profits from logging. Geographically squeezed in between the huge landholdings of the CFC to the north and of the 'bush' SDAs in central Marovo, United Church groups with their more limited lands were disadvantaged in concrete terms, while most of their villages shared the problems of erosion of customary authority shown among the SDAs. In the Roviana Lagoon area of western New Georgia problems were centred on the polarisation between an economically declining United Church and a financially expanding CFC, once a detested breakaway movement. The level of land disputes among United Church people has been staggering, nowhere as much as in the old heartland of the church in west-central Roviana. As among the SDAs, timber royalties have been largely wasted on consumption and short-term benefits. In the most recent years, the United Church has been hit even harder by the emergence of a new breakaway movement that claims to represent the true Wesleyan faith.

And so the forests and the land, the people, their social life and rural economies have been transformed in recent decades all over the Western Solomons, as in so many other parts of Melanesia. What is notable from the vantage point of New Georgia is the way in which three very different church dominations, each of which pervades most dimensions of everyday life in its adherent villages, have followed strongly diverging paths in relation to the complex local-global entanglements of the forests that grow on their customary land. The diversity of strategies and outcomes from both local and global agents defy any simplistic image of rural Solomon Islanders as passive victims of ruthless foreign companies, although invariably the Asian companies make by far the most money from the trees that are felled and exported as round logs.

\section{The New Anthropogenic Landscape and the 'Time of Development'}

The ragged and chaotic post-logging condition of much of central Marovo has certainly prevented the place from ever again approaching World Heritage listing, and the efforts of international conservationists in the area seem to have been without much result. There is much current uncertainty among the SDA 
and United Church villagers of the area as to the future of the forest. Perhaps the likely scenario is one of gradual regeneration through disuse and neglect - a somewhat extreme case of Whitmore's gap-phase paradigm, made more difficult by the environmental destruction that has taken place through the compacting and erosion of soil. This is not so in the northern areas under CFC control, where the government's Standard Logging Agreement (in most cases blatantly ignored by companies once signed) has been largely adhered to owing to the close connections between companies and church leadership: forest near water catchments is left undisturbed, no logging is carried out on high slopes, and roads are gravelled.

More significantly, the forest landscape that is now emerging after logging in the areas controlled by the CFC represents a new stage in New Georgia's anthropogenic forest; another transformation across the piru-manavasa ('wilddomesticated') continuum. On both sides of logging roads that run parallel to the coast a few hundred metres inland are family-operated blocks of tree plantations where some food crops are also grown in interspersed fashion. These are the lands now known throughout the Solomons to support huge, rapidly growing stands of teak, the valuable harvest of the future, and from the point of view of the leaders and working people of the CFC the fast-growing tree plantations amount to a sustainable enrichment of customary land. That argument does not go down well with conservationists who point out that lowland rainforest was actually removed to make room for the stands of teak, but those arguments do not go down well with the people of the CFC. It has in fact been pointed out to me in conversations with eager tree planters of the CFC that this as good as permanent transformation of parts of the lowland forest into 'something more useful' is not unlike the permanent 'domestication' of inland forest that took place in the old days, when gentle slopes near streams were cleared and became the sites for large assemblages of stone terraces for taro irrigation.

Two key locations of the CFC today display the highest degree of planned land and forest transformation anywhere in the Western Solomons. In a sheltered inlet on the exposed Kusaghe coast of north-west New Georgia lies Paradise, a large village founded in the 1950s by the Holy Mama, on the grounds of a former village called Menakasapa. Paradise was for several decades the very demonstration site for the CFC's successful and disciplined communal life. Houses there are still organised in orderly rows, and somewhat stricter regulations apply to everyday life here than elsewhere within the CFC movement. The flat coastal land around the village and inlet is fully planted with coconuts. When travelling the choppy seas of the 'Kula Gulf' between Kusaghe and Kolobangara, a sweeping view can be had of the slopes behind Paradise, which are totally planted with well-circumscribed sectors of Gmelina, Eucalyptus and teak trees (Figure 3.2). This is where, over a few days in 2000 in a now legendary event, hundreds of 
people cleared the entire hillside of residual post-logging vegetation and rapid regrowth, then planting thousands of tree saplings. In this capacity Paradise entered the twenty-first century as the CFC's demonstration site for the new era of tree plantations, although no longer the headquarters of the movement.

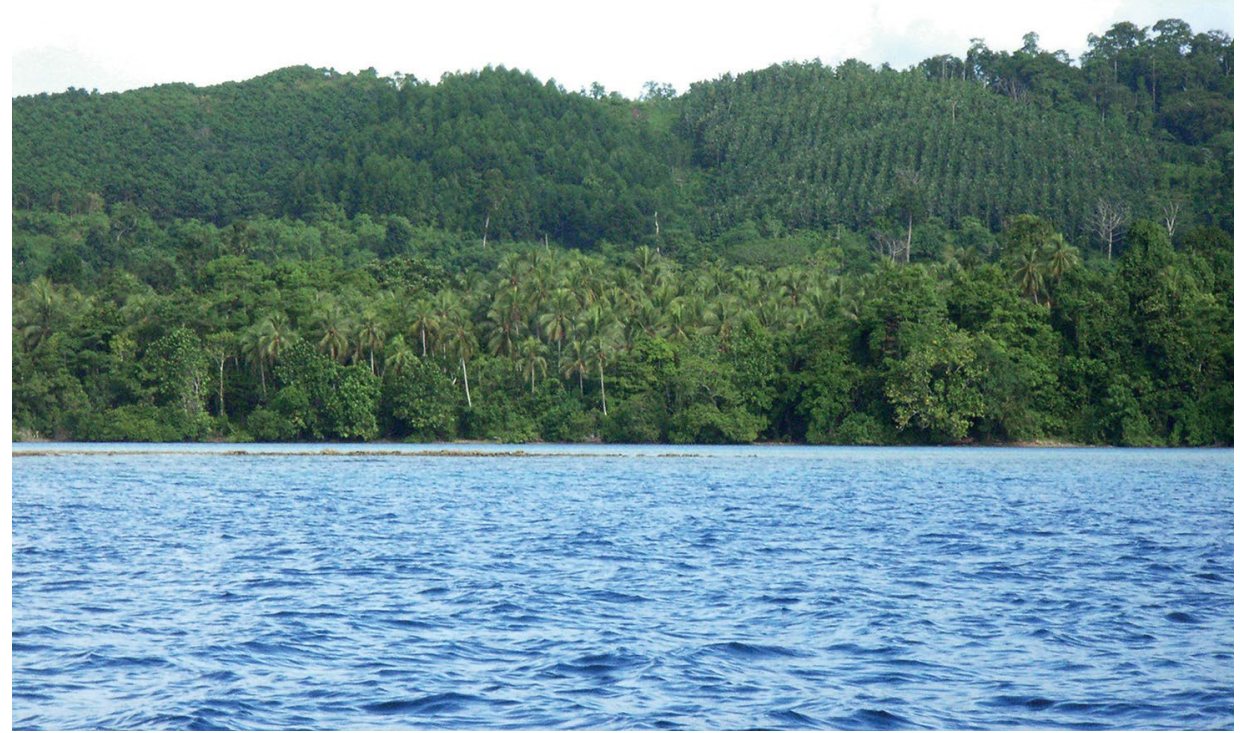

Figure 3.2 Tree plantations at Paradise village: Gmelina, Eucalyptus and teak in distinct blocks.

Source: Photo by Edvard Hviding, 2005.

The Paradise event, with minor modifications, has informed commonplace procedure for the CFC when transforming hillside rainforest to tree plantations. Usually, to take advantage of machinery, the logging company operating in an area destined for a new plantation is requested by the CFC to fell more than its usual repertoire of trees, and to clear away debris with bulldozers. The largescale communal clearing and planting, with the participation of church members from a wide area, then becomes a rapid process, after which the local landholders will have the task of maintaining the growing trees and keeping the plantations clean from encroaching vegetation. Often, to maximise usefulness, new hillside tree plantations behind CFC villages combine as food gardens with the dense growth of selected garden crops (sweet potato, cassava, pineapple, etc.) protecting the plantation soil from the blazing sun. 
From about 1990 the CFC has had its headquarters at Duvaha, the site of a large primary boarding school, on the mangrove-fringed lagoon coast of North New Georgia, and centrally placed in the Kalikolo area, which is the CFC's historical heartland (Figure 3.3). In and near Duvaha are several large modern houses belonging to the CFC leadership, and behind the village area at an elevation of about 50 metres are the former logging roads lined with lush tree plantations about 100 metres to each side, divided into family-held bloko or 'blocks'. The children who attend the boarding school come from several villages and hamlets throughout the Kalikolo and Kusaghe areas, and their families take turns to live at Duvaha and care for the entire school through food production, cooking and communal work. While there, they also tend to allocated work in the tree plantations, whether their own or those of relatives. Today's CFC strongholds like Paradise and, particularly, Duvaha, demonstrate a level of work organisation and a level of development ambition and leadership allegiance echoing Methodist Mission strongman Reverend J.F. Goldie's 'industrial mission', in which New Georgians were taught 'that the development of their land is a Christian duty and that labour is honourable' (in Bennett 2000: 45). Given that the Holy Mama claimed to have inherited the Holy Spirit from Goldie, these connections in thought and practice are not surprising — but today's 'development' is firmly in local hands.

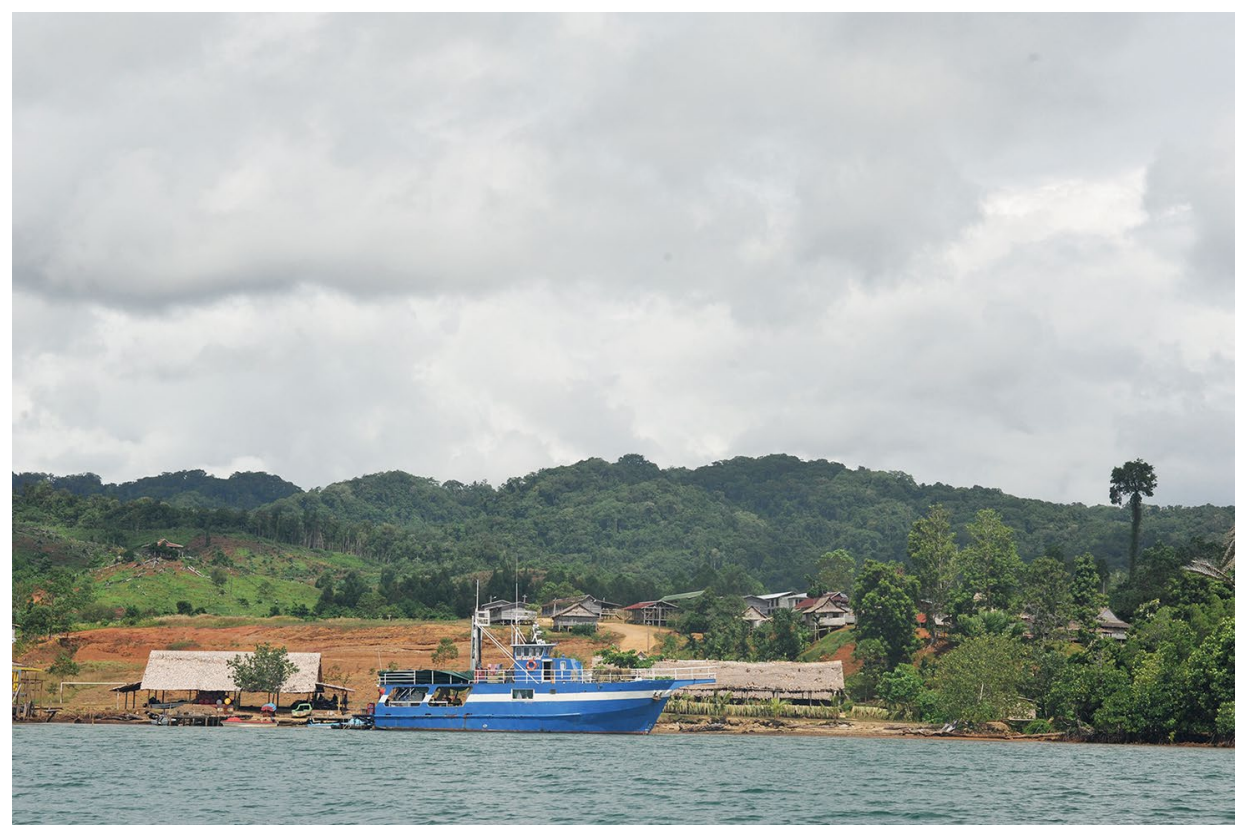

Figure 3.3 'The Time of Development': Duvaha, North New Georgia.

Source: Photo by Edvard Hviding, 2012. 
Duvaha also demonstrates other approaches to recreating the land. A few hundred metres along the mangrove-fringed coast is one of the large log shipment ponds of the Golden Springs company, in all its grimness visualising the intimate relationship between church and company in the Spiritual Authority's designated 'time of development'. Further ahead, accessible through a crocodile-infested mangrove channel, footpaths lead to the most recent land transformation by the CFC at a place called Kelehae: a huge food garden for the Duvaha population, covering all the slopes of a low, circular crater-like basin that is hidden from the lagoon by a low coastal ridge. This singular topographical form, until recently covered by coastal forest interspersed with some small swiddens, has been fully cleared and thoroughly domesticated under the leadership of the former provincial secretary of the Western Solomons, Mr Narcilly Pule. This massive effort has produced a food garden of a scale not seen in New Georgia for a very long time, echoing the so-called chigo lavata or 'huge communal swiddens' cultivated by the bush dwellers of the old days. Integrated with irrigated ruta pondfields in a continuous 'wet-and-dry' cultivation system, chigo lavata were used to build up large surpluses of yams and dryland taro for cyclical feasts. At Kelehae, the radically transformed land reflects the CFC's revival of selected practices of the past.

The impressive rural machinery of the CFC has been significantly altered in recent years through the long illness of the Spiritual Authority. Having suffered from several strokes, he remained largely immobile and unable to speak after 2010, leading a secluded yet itinerant life on board his ship MV Silent One, a former research and live-aboard diving vessel of 30 metres which he purchased in 2008 (reportedly for SBD 3 million). When he died in June 2014, several years had passed during which his sons and circle of advisers had been locked in conflict over the future religious orientation, leadership and financial management of the church with the Spiritual Authority's surviving siblings, led by his younger brother the Hon. Job Dudley Tausinga. In the process, the closeknit CFC villages throughout New Georgia split into two factions, as the central authorities of the church expelled Tausinga, his sons and the other siblings of the disabled Spiritual Authority, justifying this radical move with irreconcilable doctrinal differences as Tausinga promoted a message of reformed leadership, with less of the elevated status attained by the Spiritual Authority (who was referred to increasingly in the Roviana-speaking areas as Tamasa Toana or 'Living God'). While the split and its consequences for the cohesion of the CFC, and the complicated matter of succession, are being sorted out, the CFC's many projects have proceeded at a somewhat slower pace, although the tree plantation bloko allocated at family level are still tended in the anticipation of the future value of teak, although who tends what may no longer be a clear-cut case in villages where the split has led to internal division, and some plantations are likely falling into disrepair. 
The Hon. J.D. Tausinga, one of the key actors on the New Georgia forest scene ever since logging started there, was the member of parliament for North New Georgia continuously from 1984 to 2014; the country's longest-serving parliamentarian ever. His illustrious political career includes the cabinet portfolios of foreign affairs, natural resources, education, and forestry, as well as deputy prime minister, several terms as opposition leader, and an almost successful bid for prime minister. At the time of his defeat in the 2014 elections (to a candidate of the other faction of the CFC), he was the deputy speaker of parliament. Meanwhile, he has been operating international business enterprises, including the non-profit import and sale of Chinese-made replicas of Yamaha outboard motors branded 'Tausinga'. The university-educated Tausinga is the youngest son of the Holy Mama and retained the CFC's presence in provincial and national politics since the days when he himself had an instrumental role in the heated political processes and local-level resistance that ultimately led to the withdrawal from Solomon Islands of Levers Pacific Timber. Outside observers were surprised when in 1989, this influential, for some notorious, person thought to be an anti-logging activist brought in a new company. In a 1997 overview of the Solomon Islands logging scene, Ian Frazer (1997: 56) commented how the anti-logging movement in the country 'suffered a major setback when Tausinga unexpectedly changed his views and threw his support behind a new foreign investor in North New Georgia, the Indonesian-based company Golden Springs International'. From the local point of view, however, Tausinga's actions were not seen in any way as an unexpected change of views, but as a fulfilment of the ambitions of the CFC to choose their own collaborators and then dictate the terms of collaboration.

From Tausinga himself comes a telling summary of development strategy in the form of a discussion paper entitled 'Economic Concept'. The paper was presented to a gathering of Western Solomons political and administrative leaders in May 2002, at the height of the 'Tension' when the Solomon Islands government was bankrupt and defunct without any rural reach, and the Western Solomons was verging on secession. Tausinga's paper can be seen as a succinct expression of CFC policy on resource development; it was intended as a substantial intellectual input into the development policy of a new state of Western Solomons and it echoes the author's many-sided personal experiences and his wide readings that include Greek philosophy, Oriental religions and Marxist economics:

The guiding principal of economic concept and plan is encapsulated on the unwritten wisdom of the spirit of the modern world and thus:

Resources are not resources until you develop them. (Tausinga 2002: 2)

The exercise we take in identifying the economic opportunities shall encourage both local and foreign investors to participate in commercial activities. (ibid.: 5) 
The incorporation of thoughts, objects, persons and institutions from outside is a foundational strategy in New Georgian ways of relating to wider worlds. And so Tausinga's accentuation of the complementary roles of local and foreign investment defines an important space between the globalised challenges of today and the situation in the old days, when the predatory approach to interisland relationships of New Georgia's polities exploited the foreign of the day. The notion that 'resources are not resources until you develop them' may seem drawn from Marxist thought, but accurately reflects certain New Georgian attitudes that come to the forefront when villagers and their leaders engage in discussion with conservation organisations (Hviding 1996a: 56-7, 365-6; 2003a). This prevailing attitude is not always well understood, and certainly expresses something quite different from an indigenous ethics of conservation. Indeed it has to do so, in an ontological context where there is no nature as distinct from culture, but simply a continuum between what is 'wild' (piru) and 'domesticated' (manavasa).

The observations I have made in Marovo and around New Georgia and the interpretations I have made over the years are those of a rural Melanesian people pursuing agendas of autonomy over an environment on which their everyday lives are based. That autonomy also includes, as reflected in Tausinga's paper, a local insistence that 'resources' may be identified as and when required, such as in the case of lowland forest being converted into (first) monetary value and (second) what is envisaged as perpetually yielding plantations of valuable hardwoods. In any case, those forests were never pristine. The 'wild' forest that is rapidly being 'domesticated' in New Georgia today is actually itself a product of regeneration, through which the domesticated forests of former generations reverted into a wilder condition. An argument is made for viewing Melanesian forest history in the longest term possible, in order to highlight the fact that present-day forest transformations may not be best understood through ideas of radical change, devastation and destruction, but, like in the New Georgia example, as complicated oscillations between more or less stable, locally defined states that engage with levels of larger scale.

\section{References}

Allen, M., 2013. Greed and Grievance: Ex-militants' Perspectives on the Conflict in Solomon Islands, 1998-2003. Honolulu: University of Hawai'i Press.

Balée, W. (ed.), 1998. Advances in Historical Ecology. New York: Columbia University Press. 
Bayliss-Smith, T. and E. Hviding, 2012. 'Irrigated Taro, Malaria and the Expansion of Chiefdoms: Ruta in New Georgia, Solomon Islands.' In M. Spriggs, D. Addison and P. Matthews (eds), Irrigated Cultivation of Colocasia esculenta in the Indo-Pacific: Biological, Social and Historical Perspectives. Osaka: National Museum of Ethnology (Senri Ethnological Studies 78).

Bayliss-Smith, T. and E. Hviding, 2014a. 'Taro Terraces, Chiefdoms and Malaria: Explaining Landesque Capital Formation in Solomon Islands.' In N.T. Håkansson and M. Widgren (eds), Landesque Capital: The Historical Ecology of Enduring Landscape Modifications. Walnut Creek (CA): Left Coast Press (New Frontiers in Historical Ecology).

Bayliss-Smith, T. and E. Hviding, 2014b. 'Landesque Capital as an Alternative to Food Storage in Melanesia: Irrigated Taro Terraces in New Georgia, Solomon Islands.' Environmental Archaeology advance article. DOI: 10.1179/1749631414Y.0000000049.

Bayliss-Smith, T., E. Hviding and T.C. Whitmore, 2003. 'Rainforest Composition and Histories of Human Disturbance in Solomon Islands.' Ambio 32(5): 346-52.

Bennett, J.A., 2000. Pacific Forest: A History of Resource Control and Contest in Solomon Islands, c. 1800-1997. Cambridge: White Horse Press and Leiden: Brill Academic Publishers.

Blaikie, P. and H. Brookfield, 1987. Land Degradation and Society. London: Methuen.

Connell, J.H., 1978. 'Diversity in Tropical Rain Forests and Coral Reefs.' Science 19: $1302-10$.

Frazer, I., 1997. 'The Struggle for Control of Solomon Island Forests.' The Contemporary Pacific 9(1): 39-72.

Hviding, E., 1996a. Guardians of Marovo Lagoon: Practice, Place, and Politics in Maritime Melanesia. Honolulu: University of Hawai'i Press.

Hviding, E., 1996b. 'Nature, Culture, Magic, Science: On Meta-Languages for Comparison in Cultural Ecology.' In P. Descola and G. Pálsson (eds), Nature and Society: Anthropological Perspectives. London: Routledge.

Hviding, E., 2003a. 'Contested Rainforests, NGOs, and Projects of Desire in Solomon Islands.' International Social Science Journal 178: 539-54. 
Hviding, E., 2003b. 'Disentangling the Butubutu of New Georgia: Cognatic Kinship in Thought and Action.' In I. Hoëm and S. Roalkvam (eds), Oceanic Socialities and Cultural Forms: Ethnographies of Experience. Oxford: Berghahn Books.

Hviding, E., 2011. 'Replacing the State in the Western Solomon Islands: The Political Rise of the Christian Fellowship Church.' In E. Hviding and K.M. Rio (eds), Made in Oceania: Social Movements, Cultural Heritage and the State in the Pacific. Wantage (UK): Sean Kingston Publishing.

Hviding, E. and T. Bayliss-Smith, 2000. Islands of Rainforest: Agroforestry, Logging and Ecotourism in Solomon Islands. Aldershot: Ashgate.

Lees, A., M. Garnett and S. Wright, 1991. A Representative Protected Forests System for the Solomon Islands. Nelson (New Zealand): Maruia Society.

Makim, A., 2002. Globalisation, Community Development, and Melanesia: The North New Georgia Sustainable Forestry and Rural Development Project. Canberra: The Australian National University, State, Society and Governance in Melanesia Program (Discussion Paper 2002/1).

McDougall, D., 2008. Religious Institutions as Alternative Structures in PostConflict Solomon Islands? Cases from Western Province. Canberra: The Australian National University, State, Society and Governance in Melanesia Program (Discussion Paper 2008/5).

Moore, C., 2004. Happy Isles in Crisis: The Historical Causes for a Failing State in Solomon Islands, 1998-2004. Canberra: Asia Pacific Press.

Robbins, P., 2004. Political Ecology: A Critical Introduction. Oxford: Blackwell.

Somerville, H.B.T., 1893. 'Report Concerning the Bush in the Vicinity of Lihihina Island, Marovo Lagoon, New Georgia, Solomon Islands.' MS report addressed to Commander A.J. Balfour, H.M.S. 'Penguin'. London: Balfour Collection, Royal Geographical Society.

Tausinga, J.D., 2002. 'Economic Concept: A Discussion Paper at Leaders' Meeting, Gizo, Western Solomons 02-04 May 2002.' Unpublished paper.

Were, E., 1970. No Devil Strings. Mountain View (CA): Pacific Press Publishing Association.

Whitmore, T.C., 1969. 'The Vegetation of the Solomon Islands.' Philosophical Transactions of the Royal Society B: Biological Sciences 255: 259-70.

Whitmore, T.C., 1984. Tropical Rain Forests of the Far East. Oxford: Clarendon Press (2nd edition). 
Whitmore, T.C., 1990. An Introduction to Tropical Rain Forests. Oxford: Clarendon Press.

Whitmore, T.C., 1995. 'Environmental Assessment of Proposed Tree Plantations on New Georgia by Solomons Sustainable Products Ltd.' Report for Commonwealth Development Corporation, London.

Whitmore, T.C., 1998. An Introduction to Tropical Rain Forests. Oxford: Oxford University Press (2nd edition).

Willis, K.J., L. Gillson and T.M. Brncic, 2004. 'How “Virgin" Is Virgin Rainforest?' Science 304: 402-3. 
This text is taken from Tropical Forests of Oceania: Anthropological Perspectives, edited by Joshua A. Bell, Paige West and Colin Filer, published 2015 by ANU Press, The Australian National University, Canberra, Australia. 